\title{
Effect of Preservation on Two Different Varieties of Vernonia amygdalina Del. (Bitter) Leaves
}

\author{
Nyerhovwo J. Tonukari1,2*, Oghenetega J. Avwioroko',2, Theresa Ezedom¹, \\ Akpovwehwee A. Anigboro ${ }^{1}$ \\ ${ }^{1}$ Department of Biochemistry, Faculty of Science, Delta State University, Abraka, Nigeria \\ ${ }^{2}$ African Research Laboratories, Otorho-Agbon, Ethiope-East LGA, Delta State, Nigeria \\ Email: ${ }^{*}$ tonukari@gmail.com
}

Received 27 March 2015; accepted 11 May 2015; published 12 May 2015

Copyright (C) 2015 by authors and Scientific Research Publishing Inc.

This work is licensed under the Creative Commons Attribution International License (CC BY). http://creativecommons.org/licenses/by/4.0/

\begin{abstract}
Vernonia amygdalina Del. is one of the leafy vegetables that can be used in an attempt to alleviate the problem of micronutrient malnutrition, prominent in tropical Africa. In order to ensure availability in non-growing areas or seasons, the vegetable needs to be preserved. Processing and preservation methods influence the nutrient content of vegetables. The present study was aimed at determining the effects of preservation on two different varieties of $V$. amygdalina (bitter) leaves (broad and small leaves). To this effect, evaluations were made on the chlorophyll content, phytochemicals, and antioxidant capacity of the two varieties of bitter leaf ( $V$. amygdalina Del.) stored at $4^{\circ} \mathrm{C}$ and $-20^{\circ} \mathrm{C}$ over a period of two weeks. Results showed a significant decrease in all parameters studied for both varieties at $-20^{\circ} \mathrm{C}$ except for the free radical reducing power (FRAP), DPPH radical scavenging activity (\%RSA) and nitric oxide radical scavenging activity (\%RSA) of $V$. amygdalina broad leaves where increase in scavenging activity was observed. Thus, it was concluded that to preserve the chlorophyll, phenol, total soluble proteins and reducing sugar levels, preservation at $4^{\circ} \mathrm{C}$ is recommended. The present study finding would be useful during short-term preservation of bitter leaves for soup preparation and/or its aqueous extract for ethnomedicinal purposes, especially the small leaf variety.
\end{abstract}

\section{Keywords}

Vernonia amygdalina, Preservation, Refrigeration, Phytonutrients, Chlorophyll, Phenolic Compounds, Antioxidant Capacities

\footnotetext{
${ }^{*}$ Corresponding author.
}

How to cite this paper: Tonukari, N.J., Avwioroko, O.J., Ezedom, T. and Anigboro, A.A. (2015) Effect of Preservation on Two Different Varieties of Vernonia amygdalina Del. (Bitter) Leaves. Food and Nutrition Sciences, 6, 633-642. 


\section{Introduction}

Vernonia amygdalina Del. (bitter leaf), a shrub or small tree that can reach 23 feet in height when fully grown with petiolate leaves of about $6 \mathrm{~mm}$ diameter and elliptic shape, belongs to the family Asteraceae. It is known as "Ewuro" in Yoruba, "Etidot" in Ibibio, "Onugbu" in Igbo, "Chusa-diki" in Hausa tribes and Origbo among the Urhobo and Itsekiri tribes in Nigeria [1]. It is cultivated in Nigeria mainly for its nutritional value [2] [3].

$V$. amygdalina is a medicinal plant and fresh bitter leaf is of great importance in human diet because of the presence of vitamins and mineral salts [4]. It is a very important protective food and useful for the maintenance of health and prevention and treatment of various diseases. The plant (especially the leaf) has been found useful in the ethnotherapy of diabetes [5]-[8], asthma, headache [9], skin infections such as ringworm, rashes and eczema, schistosormiasis, malaria [10], measles, diarrhea, tuberculosis, abdominal pain and intestine complaints as well as fevers, cough [11], induction of fertility in barren women [12]-[14] and hyperlipidemia [15]. Bitter leaf also helps to cleanse vital organs of the body like the liver and the kidney.

Phytochemicals contained in V. amygdalina include saponins, sesquiterpenes, lactones and flavonoids, steroid glucosides such as vernoniosides A1, A2, A3, A4, B1, B2, B3 [5] as well as vitamins and minerals [16]. These chemical substances possess a potent anti-parasitic, anti-tumour, and bactericidal effect. It can also be used, instead of hops, in making beer [17] and also found in homes in villages as fence post and post-herb [17].

Despite the wide application of bitter leaf and its high nutritional content, very little attempt has been made on preserving this vegetable. The vegetable is usually consumed either in the very fresh state or as dried leaves. Hence the current study focuses on the effect of preservation on two different varieties of V. amygdalina (bitter) leaves.

\section{Materials and Methods}

\subsection{Experimental Design}

V. amygdalina Del. leaves' varieties of broad and small leaves were respectively collected from Harmony Path Farms in Otorho-Agbon, Delta State, Nigeria and put in well labeled polythene containers (two for each variety). The samples were then preserved in a refrigerator $\left(4^{\circ} \mathrm{C}\right)$ and freezer $\left(-20^{\circ} \mathrm{C}\right)$ for 2 weeks before leaf extraction. Fresh leaves (broad and slender) were also collected from the same pumpkin plants on the day of extraction to serve as control for the preserved ones. Thereafter, several biochemical analyses were carried out on the leaf extracts to ascertain the effect of preservation on the nutritional, phytochemical and antioxidant potentials of the preserved bitter leaves relative to the fresh control leaves.

\subsection{Aqueous Leaf Extraction}

$1 \mathrm{~g}$ of broad and slender bitter leaf varieties were weighed, respectively, with an electronic balance (SPEC 21, England) and thereafter homogenized in a cold medium using $0.1 \mathrm{M}$ phosphate buffer (pH 7.2) and the final volumes made to $50 \mathrm{ml}$ with same buffer respectively, making a $2 \% \mathrm{w} / \mathrm{v}$ of the leaf extracts. The homogenates were filtered with a sieve cloth and the filtrate further centrifuged at $3000 \mathrm{~g}$ for $10 \mathrm{~min}$. The later filtrates were used for subsequent analyses as the aqueous leaf extracts of both bitter leaf varieties (carefully labeled).

\subsection{Estimation of Chlorophyll Content}

The chlorophyll content of the leaves was determined according to the method described by [18] [19] with some little modifications. About $500 \mathrm{mg}$ of leaf samples were weighed and ground with $50 \mathrm{ml}$ of distilled water in a pestle and mortar. It was then centrifuged at $4000 \mathrm{rpm}$ for $10 \mathrm{~min}$ till a clear supernatant was obtained. Absorption was measured, using a spectrophotometer at 645 and $663 \mathrm{~nm}$ and chlorophyll content (mg/g fw) was calculated using the equation:

$$
\text { Chlorophyll } \mathrm{a}+\mathrm{b}=8.02\left(\mathrm{~A}_{663}\right)+20.21\left(\mathrm{~A}_{645}\right) .
$$

Three replicates were made of each treatment.

\subsection{Determination of Total Flavonoid Contents of Extract}

This was determined by colorimetry using a method described by [20] with some modifications. $250 \mu \mathrm{l}$ of the extract was added to $1.25 \mathrm{ml}$ of distilled water and $75 \mu \mathrm{l}$ of $5 \% \mathrm{NaNO}_{2}$. After $5 \mathrm{~min}, 150 \mu \mathrm{l}$ of $10 \% \mathrm{AlCl}_{3} . \mathrm{H}_{2} \mathrm{O}$ 
was added, followed by $500 \mu \mathrm{l}$ of $1 \mathrm{M} \mathrm{NaOH}$ and $275 \mu \mathrm{l}$ of distilled water after $6 \mathrm{~min}$. The solution was properly mixed and the colour intensity of the mixture read at $510 \mathrm{~nm}$. Catechin was used as the standard.

\subsection{Determination of Total Phenol Content of Extract}

This was carried out according to the method described by [21]. $1 \mathrm{ml}$ of Folin C reagent was added to $1 \mathrm{ml}$ of the sample. After $3 \mathrm{~min}, 1 \mathrm{ml}$ of saturated $\mathrm{Na}_{2} \mathrm{CO}_{3}$ solution was added and the solution was made up to $10 \mathrm{ml}$ with distilled water. The reaction mixture was kept in the dark for $90 \mathrm{~min}$. The absorbance was read at $725 \mathrm{nml}$. Catechin was used as the standard.

\subsection{Determination of Reducing Power of Extract}

This was estimated using the method of [22]. $2.5 \mathrm{ml}$ of $200 \mathrm{mM}$ of phosphate buffer (pH 6.6) and $2.5 \mathrm{ml}$ of $1 \%$ $\mathrm{K}_{3} \mathrm{FeCN}$ were added to various concentrations of the extract. The mixture was incubated for $2 \mathrm{~min}$ at $50^{\circ} \mathrm{C}$ and then centrifuged at $1000 \mathrm{~g}$ for $8 \mathrm{~min} .5 \mathrm{ml}$ of the supernatant was then mixed with $5 \mathrm{ml}$ of distilled water and 1 $\mathrm{ml}$ of $0.1 \% \mathrm{FeCl}_{3}$. The absorbance of the mixture was measured at a wavelength of $700 \mathrm{~nm}$. Catechin was used as the standard.

\subsection{2, 2-Diphenyl-1-Picrylhydrazyl Radical (DPPH॰) Scavenging Activity of Extract}

This was estimated according to the method described by [23]. To $0.3 \mathrm{ml}$ of the extract, $2.7 \mathrm{ml}$ methanolic solution of DPPH radical $\left(6 \times 10^{-5} \mathrm{~mol} / \mathrm{l}\right)$ was added. The mixture was shaken vigorously and left to stand for 60 min in the dark until stable absorption values could be obtained. The reduction of the DPPH radical was determined by measuring the absorption at $517 \mathrm{~nm}$.

$$
\% \text { RSA }=\frac{A_{\text {DPPH }}-A_{S}}{A_{D P P H}} \times 100
$$

where, \%RSA = Percentage of DPPH decolouration; $A_{D P P H}=$ absorbance of DPPH solution; $A_{S}=$ absorbance of the solution when the sample was added at a particular level.

\subsection{Nitric Oxide Radical Scavenging Assay}

The scavenging effect on nitric oxide ( $\mathrm{NO}^{\circ}$ ) radical was measured according to the method of [24]. $0.5 \mathrm{ml}$ of the leaf extract was added in the test tubes to $1 \mathrm{ml}$ of sodium nitroprusside solution $(25 \mathrm{mM})$ and the tubes incubated at $37^{\circ} \mathrm{C}$ for $2 \mathrm{~h}$. An aliquot $(0.5 \mathrm{ml})$ of the incubation solution was removed and diluted with $0.3 \mathrm{ml}$ of Griess reagent (1\% sulphanilamide in $5 \% \mathrm{H}_{3} \mathrm{PO}_{4}$ and $0.1 \%$ naphthylethylenediamine dihydrochloride). The absorbance of the chromophore formed was immediately read at $570 \mathrm{~nm}$ against distilled water as blank with catechin $(50 \mu \mathrm{g})$ used as standard. Results were expressed as percentage radical scavenging activity (RSA):

$$
\% \text { RSA }=1-\frac{\Delta \text { Abs of sample }}{\Delta \text { Abs of control }} \times 100 \text {. }
$$

\subsection{Reducing Sugar Determination Assay}

This was carried out using the 3, 5-dinitrosalicylic acid (DNS) colorimetric method [25]. $1.5 \mathrm{ml}$ of DNS reagent was added to $1.5 \mathrm{ml}$ of leaf extract in a lightly capped test tube. (To avoid the loss of liquid due to evaporation, the test tube was covered with a piece of paraffin film since a plain test tube was used). Heat was applied to the mixture at $90^{\circ} \mathrm{C}$ for 5 - $15 \mathrm{~min}$ to develop the red-brown color. Then, $0.5 \mathrm{ml}$ of a $40 \%$ potassium sodium tartrate (Rochelle salt) solution was added to stabilize the color. After cooling to room temperature in a cold water bath, the absorbance was recorded with a spectrophotometer at $575 \mathrm{~nm}$.

\subsection{Total Protein Determination by Biuret Method}

Protein concentration of the various samples was determined by means of the Biuret method as described by [26] with some modifications: Potassium iodide was added to the reagent to prevent precipitation of $\mathrm{Cu}^{2+}$ ions as cuprous oxide. $1 \mathrm{ml}$ of the diluted sample was taken and added to $3 \mathrm{ml}$ of Biuret reagent. The mixture was incubated at room temperature for $30 \mathrm{~min}$ after which the absorbance was read at $540 \mathrm{~nm}$ using distilled water as 
blank. Bovine serum albumin (BSA) was used as standard protein and the protein content of the samples was extrapolated from the BSA standard curve.

\section{Results and Discussion}

Results on the effects of preservation (refrigeration at $4^{\circ} \mathrm{C}$ and freezing at $-20^{\circ} \mathrm{C}$ ) on the chlorophyll content, phytochemicals, and antioxidant capacity of the two varieties of bitter leaf ( $V$. amygdalina) studied over a period of two weeks are shown below. The results showed a significant decrease $(\mathrm{p}<0.05)$ in the chlorophyll content of both species of $V$. amygdalina at $4{ }^{\circ} \mathrm{C}$ and $-20^{\circ} \mathrm{C}$ compared to the respective controls (Figure 1). From the results, at $4^{\circ} \mathrm{C}$, percentage decrease in chlorophyll a and b contents is $72.33 \%$ for $V$. amygdalina broad while the percentage decrease was $51.48 \%$ for $V$. amygdalina small when compared to the respective controls. Thus, $V$. amygdalina broad lost more of its chlorophyll content at $4^{\circ} \mathrm{C}$ compared to $V$. amygdalina small. However, at $-20^{\circ} \mathrm{C}$, the decrease in cholorophyll a and $\mathrm{b}$ for both varieties shows no statistical difference. Thus at freezing condition, the chlorophyll content of V. amygdalina is significantly lost irrespective of specie. Cătunescu et al. [27] showed a decrease in chlorophyll contents of minimally processed parsley (Petroselinum crispum), dill (Anethum graveolens) and lovage (Levisticum officinale) subjected to cold storage at $4^{\circ} \mathrm{C}$. Agüero et al. [28] also reported decrease in the chlorophyll content of external, middle, and internal zones of lettuce heads (Lactuca sativa $\mathrm{L}$.) stored at $0^{\circ} \mathrm{C}-2^{\circ} \mathrm{C}$ and $97 \%$ to $99 \%$ relative humidity.

Enzymatic degradation of chlorophyll a and b caused by chlorophyllase may occur during frozen storage [29]. During storage, vegetables containing chlorophyll undergo changes or loss of color [30]-[32]. Environmental factors such as light, temperature, humidity, oxygen and ethylene [33] [34] and inner plant factors such as chlorophyllase and magnesium dechelactase activity [35] [36] are responsible for the loss of chlorophyll pigments during green vegetable storage.

Chlorophyll content was determined along the storage period in order to assess both the visual quality of the samples (green index) and its nutritional quality. Chlorophyll is considered crucial to final product acceptance, because green color is associated with fresh vegetables quality [37]. Also, chlorophyll may prove to have disease-protective effects attributed to diets rich in green vegetables because its content in these plants is much higher in concentrations than the widely studied phytochemicals [38].

Figure 2 shows that refrigeration at $4^{\circ} \mathrm{C}$ and freezing at $-20^{\circ} \mathrm{C}$ for two weeks significantly $(\mathrm{p}<0.05)$ affected the phenolic content extract of both varieties of bitter leaf. $V$. amygdalina small showed a more significant decrease at $4^{\circ} \mathrm{C}$ compared to $V$. amygdalina broad while the changes showed no significant difference $(\mathrm{p}<0.05)$ at $-20^{\circ} \mathrm{C}$ between both varieties. In cherries, the amount of total phenolics was evaluated throughout frozen storage for 6 months at $-23^{\circ} \mathrm{C}$ and $-70^{\circ} \mathrm{C}$ by [39] and they reported $25 \%$ degradation after 3 months and $50 \%$ after 6 months at the higher temperature, with minimal changes at the lower temperature. Thus, the decrease in phenolic compounds in vegetables could be both temperature and time dependent. The phenolic composition of fruit and

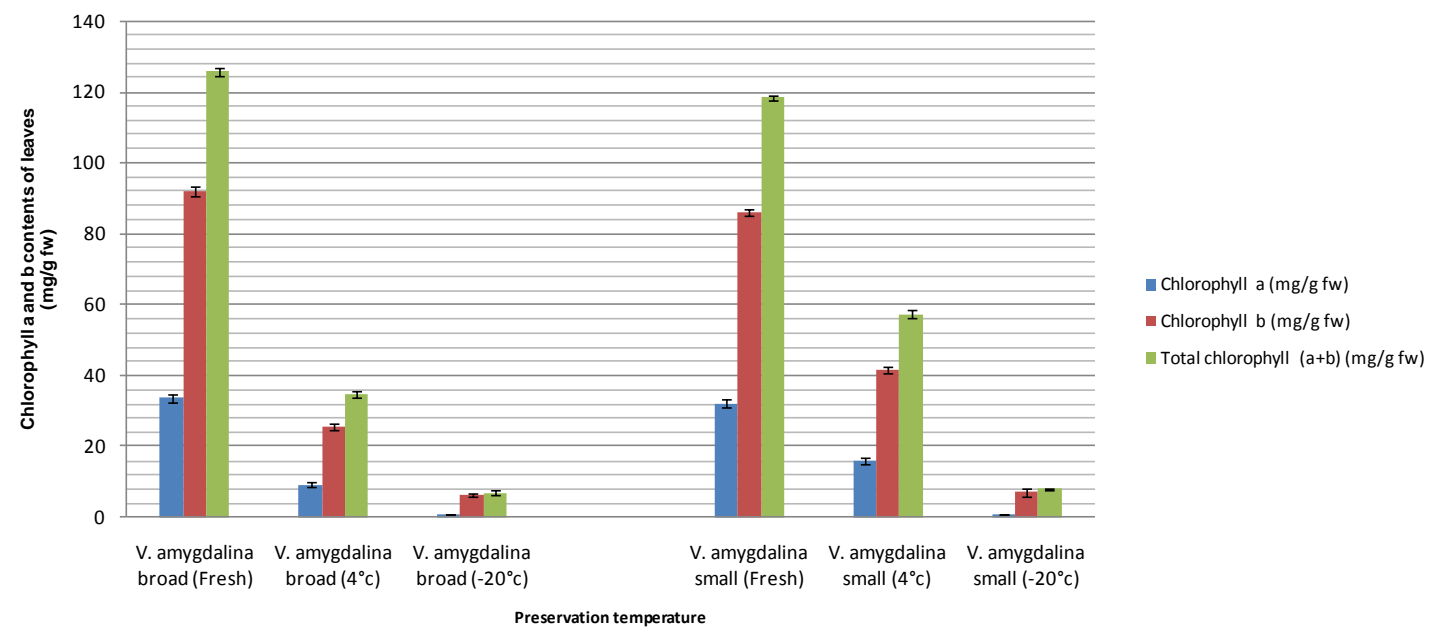

Figure 1. Effect of preservation on chlorophyll a and b contents $\left(\mathrm{mg} / \mathrm{g}\right.$ fw) of leaves. $4^{\circ} \mathrm{C}$, leaves preserved by refrigeration $\left(4^{\circ} \mathrm{C}\right)$ for two weeks; and $-20^{\circ} \mathrm{C}$, leaves preserved by freezing $\left(-20^{\circ} \mathrm{C}\right)$ for two weeks. 


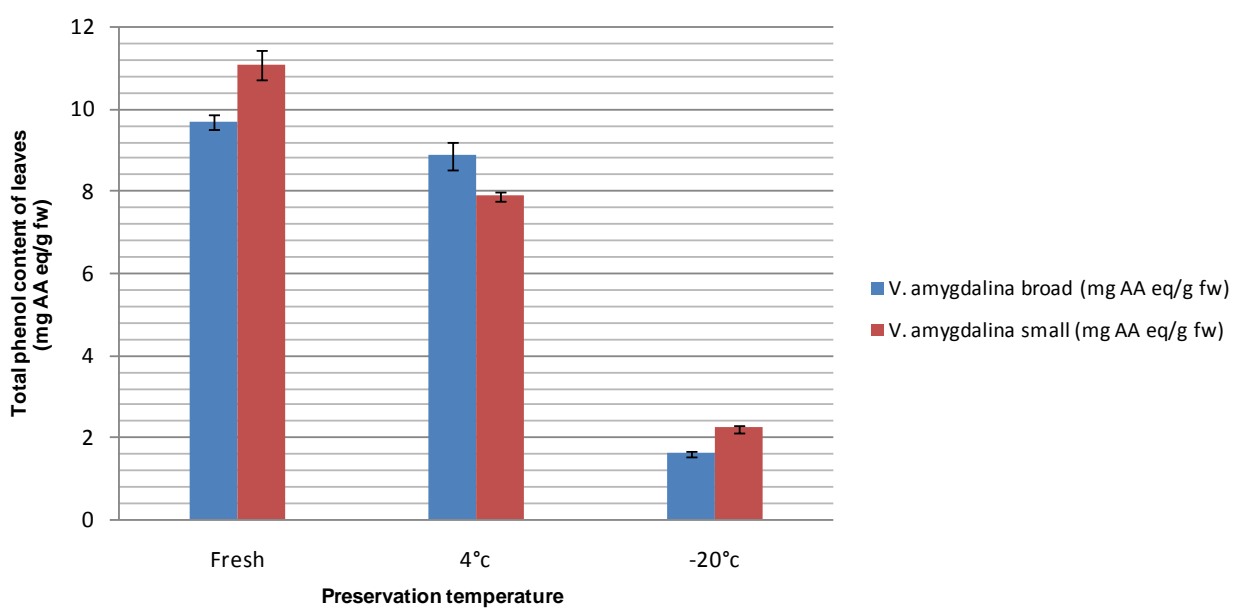

Figure 2. Effect of preservation on total phenol content extract (mg AA eq $/ \mathrm{g} \mathrm{fw}$ ) of leaves. $4^{\circ} \mathrm{C}$, leaves preserved by refrigeration $\left(4^{\circ} \mathrm{C}\right)$ for two weeks; and $-20^{\circ} \mathrm{C}$, leaves preserved by freezing $\left(-20^{\circ} \mathrm{C}\right)$ for two weeks.

vegetables is also dependent on commodity, cultivar, maturity stage and post-harvest storage handling and storage conditions. Since phenolic compounds are antioxidants, they are subject to oxidation during storage and processing. Chemical degradation of phenols can still occur during storage, depending on available oxygen and exposure to light [40]. Phenolic compounds are also water-soluble, rendering them susceptible to leaching. In terms of flavonoid content, $V$. amygdalina broad showed a significant increase in flavonoid content after refrigeration at $4^{\circ} \mathrm{C}$ (Figure 3). However, at $-20^{\circ} \mathrm{C}$, there was a decrease in the flavonoid content which is highly significant $(\mathrm{p}<0.05)$. V. amygdalina small however, showed significant $(\mathrm{p}<0.05)$ decrease in flavonoid content at both $4^{\circ} \mathrm{C}$ and $-20^{\circ} \mathrm{C}$. Phenol and flavonoid are antioxidants that play major roles in the protection of cells from lethal effects of free radicals and their derivatives [41]. A diet rich in antioxidant compounds (like phenols and flavonoids) therefore helps to strengthen the antioxidant-based defense system in the human body [42] [43].

Total soluble protein and reducing sugar of $V$. amygdalina broad showed decrease at $4{ }^{\circ} \mathrm{C}$ which became highly significant $(\mathrm{p}<0.05)$ at $-20^{\circ} \mathrm{C}$ (Figure 4, Figure 5). V. amygdalina small on the other hand showed highly significant decrease at both temperatures. The decrease in total sugars may be attributed to conversion of glucose into starch during storage. Also, hydrolysis of sucrose could account for the decrease [44]. At low temperature, the linear amylose molecules aggregate together to crystallize, and the water held between their structures is released which could lead to decrease in total soluble sugar [45]. Singh et al. [45] also reported decrease in refrigerated $\left(4^{\circ} \mathrm{C}\right)$ and frozen $\left(-18^{\circ} \mathrm{C}\right)$ Indian water chestnut.

In this study, the ferric reducing antioxidant power (FRAP) of the fresh and preserved bitter leaves was determined and reported (Figures 6-8). Free radical reducing power (FRAP), DPPH radical scavenging activity (\%RSA) and nitric oxide radical scavenging activity (\%RSA) of $V$. amygdalina broad leaves were significantly $(\mathrm{p}<0.05)$ increased at both $4^{\circ} \mathrm{C}$ and $-20^{\circ} \mathrm{C}$ with a higher level at $-20^{\circ} \mathrm{C}$. However, the nitric oxide radical scavenging activity (\%RSA) showed a slight decrease at $-20^{\circ} \mathrm{C}$ compared to the level at $4^{\circ} \mathrm{C}$. In like manner, $V$. amygdalina small leaves showed significant increase in DPPH radical scavenging activity at temperatures $4^{\circ} \mathrm{C}$ and $-20^{\circ} \mathrm{C}$, with a higher scavenging activity at $-20^{\circ} \mathrm{C}$. The FRAP was also significantly decreased at both storage conditions while for the nitric oxide radical scavenging activity (\%RSA), a decrease was observed only at $-20^{\circ} \mathrm{C}$ while remaining constant at $4^{\circ} \mathrm{C}$ when compared to the control. The results generally show that there was increase in reducing power of the stored vegetable at both storage conditions. The result of the scavenging activity assays indicates that the vegetable was potentially active at both refrigerating and freezing conditions. This suggests that the plant extract contains compounds that are capable of donating hydrogen to free radicals (chemical species with lone pair electrons) thereby reducing such radicals or reactive species to their inert states and this could help to prevent free radical-induced cellular damage in individuals that consume this vegetable as part of their regular diets [24] [41].

\section{Conclusion}

Investigations carried out in the current study showed that at both preservation conditions, chlorophyll content 


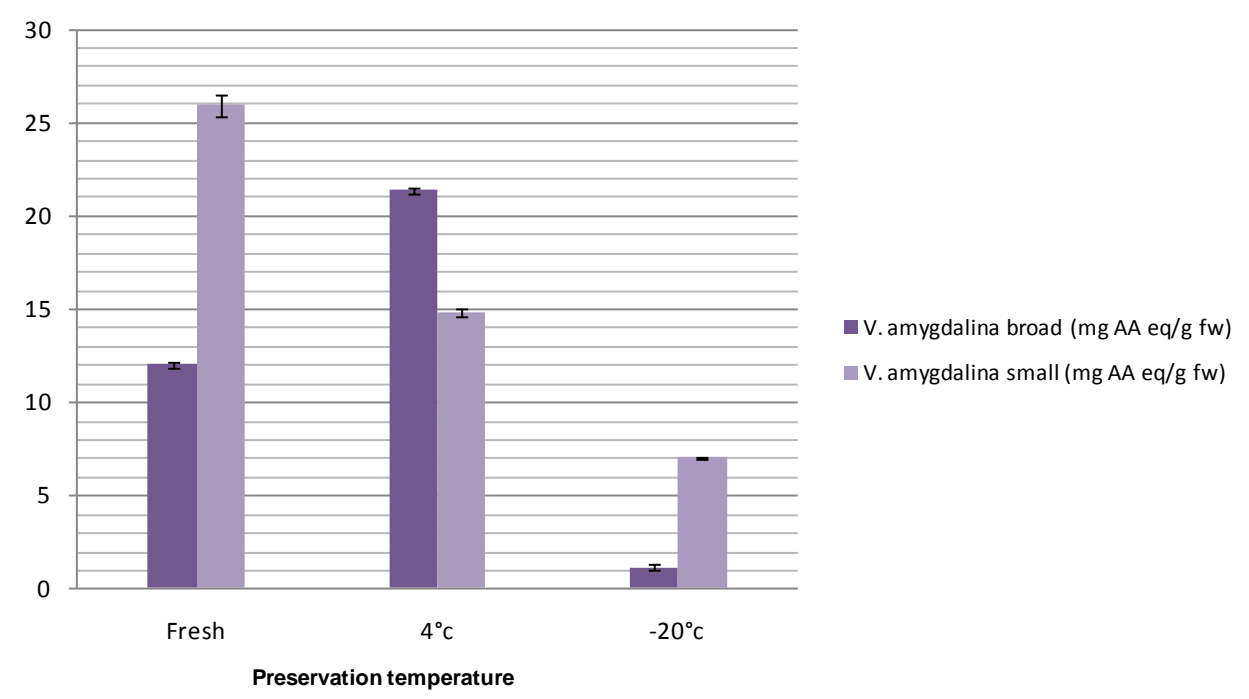

Figure 3. Effect of preservation on total flavonoid content extract (mg AA eq/g fw) of leaves. $4^{\circ} \mathrm{C}$, leaves preserved by refrigeration $\left(4^{\circ} \mathrm{C}\right)$ for two weeks; and $-20^{\circ} \mathrm{C}$, leaves preserved by freezing $\left(-20^{\circ} \mathrm{C}\right)$ for two weeks.

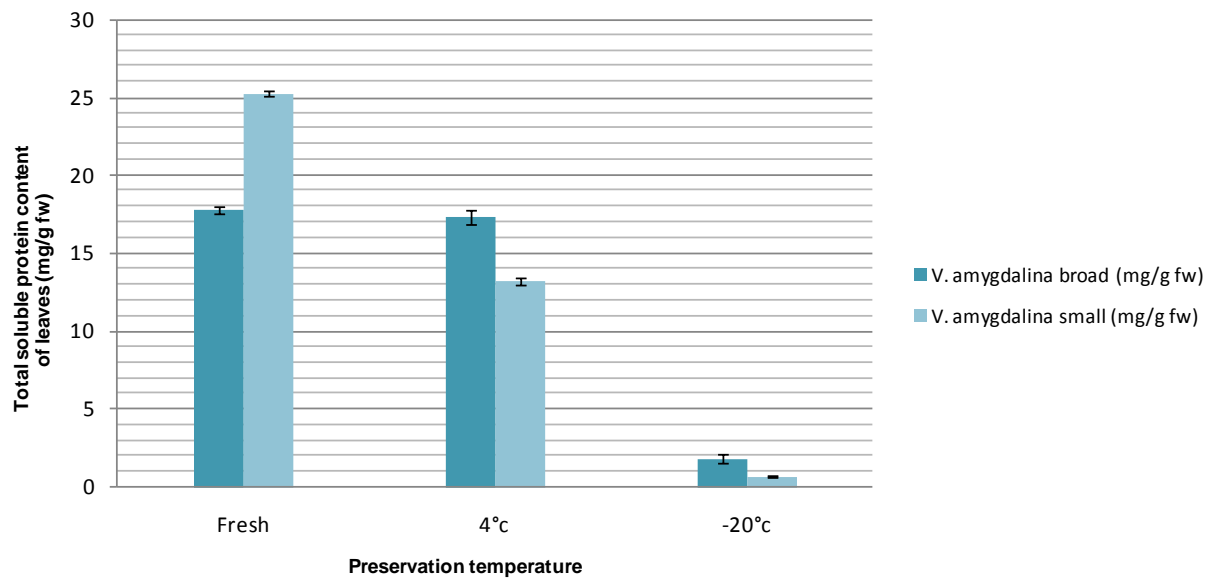

Figure 4. Effect of preservation on total soluble protein content (mg/g fw) of leaves. $4^{\circ} \mathrm{C}$, leaves preserved by refrigeration $\left(4^{\circ} \mathrm{C}\right)$ for two weeks; and $-20^{\circ} \mathrm{C}$, leaves preserved by freezing $\left(-20^{\circ} \mathrm{C}\right)$ for two weeks.

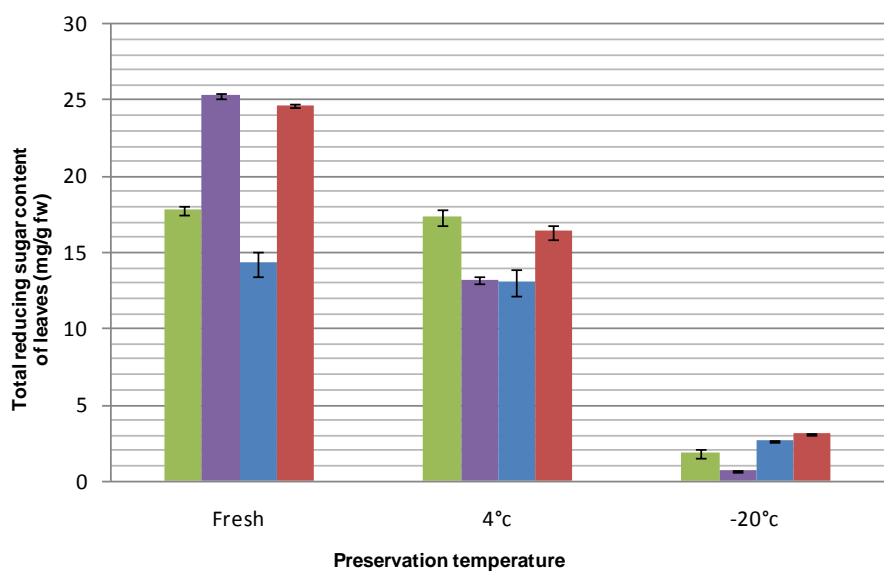

$\square$ V. amygdalina broad $(\mathrm{mg} / \mathrm{g} \mathrm{fw})$

- V. amygdalina small $(\mathrm{mg} / \mathrm{g} \mathrm{fw})$

- V. amygdalina broad $(\mathrm{mg} / \mathrm{g} \mathrm{fw})$

- V. amygdalina small ( $\mathrm{mg} / \mathrm{g} \mathrm{fw}$ )

Figure 5. Effect of preservation on total reducing sugar content (mg/g fw) of leaves. $4^{\circ} \mathrm{C}$, leaves preserved by refrigeration $\left(4^{\circ} \mathrm{C}\right)$ for two weeks; and $-20^{\circ} \mathrm{C}$, leaves preserved by freezing $\left(-20^{\circ} \mathrm{C}\right)$ for two weeks. 


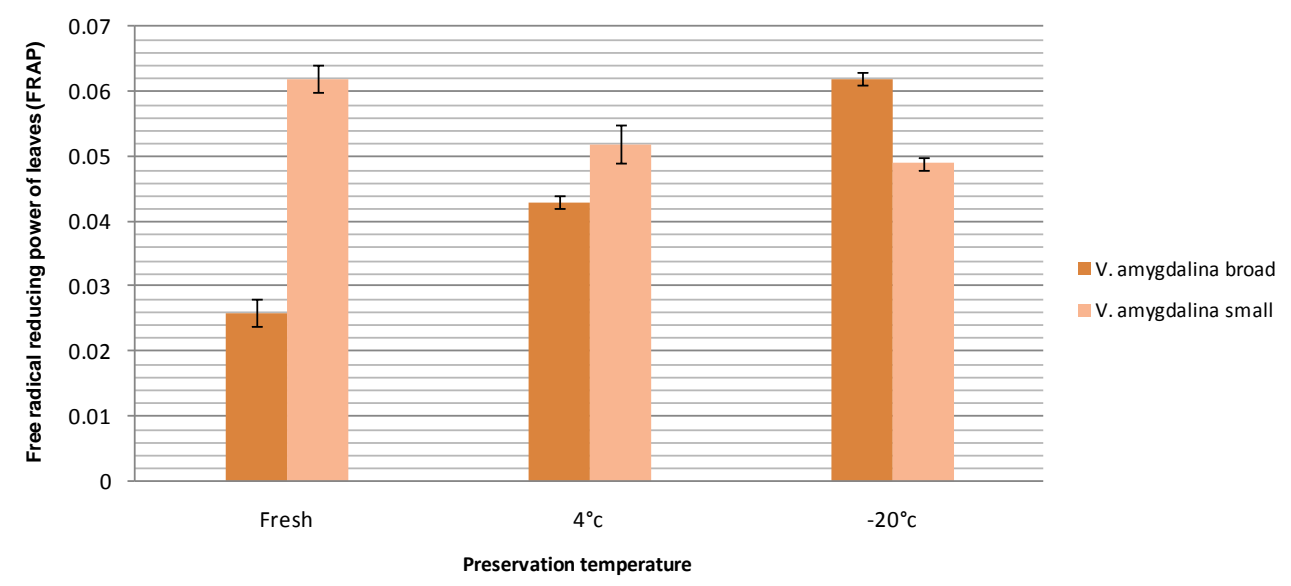

Figure 6. Effect of preservation on free radical reducing power (FRAP) of leaves. $4^{\circ} \mathrm{C}$, leaves preserved by refrigeration $\left(4^{\circ} \mathrm{C}\right)$ for two weeks; and $-20^{\circ} \mathrm{C}$, leaves preserved by freezing $\left(-20^{\circ} \mathrm{C}\right)$ for two weeks.

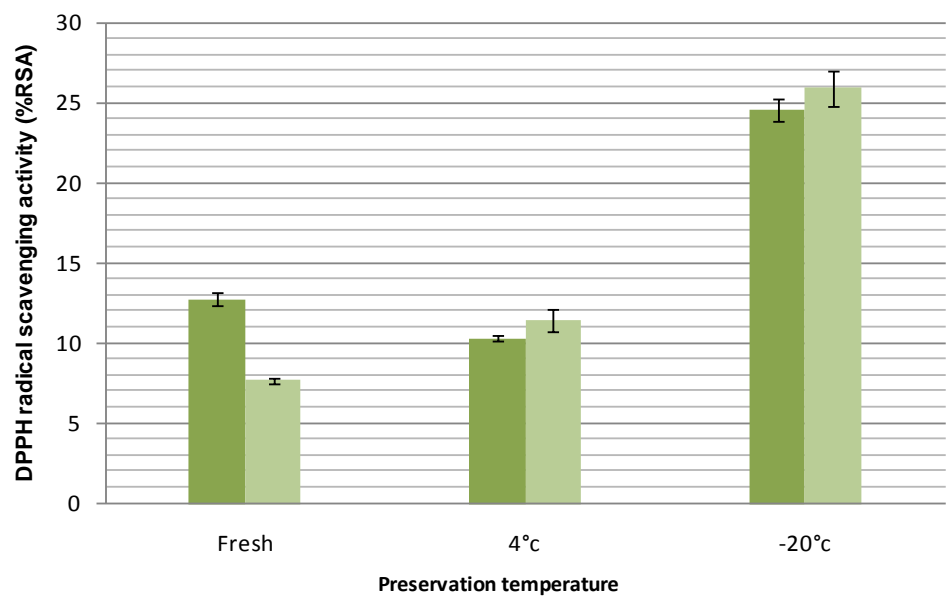

V. amygdalina broad (\%RSA)

$\square$ V. amygdalina small (\%RSA)

Figure 7. Effect of preservation on DPPH radical scavenging activity (\%RSA) of leaves. $4^{\circ} \mathrm{C}$, leaves preserved by refrigeration $\left(4^{\circ} \mathrm{C}\right)$ for two weeks; and $-20^{\circ} \mathrm{C}$, leaves preserved by freezing $\left(-20^{\circ} \mathrm{C}\right)$ for two weeks.

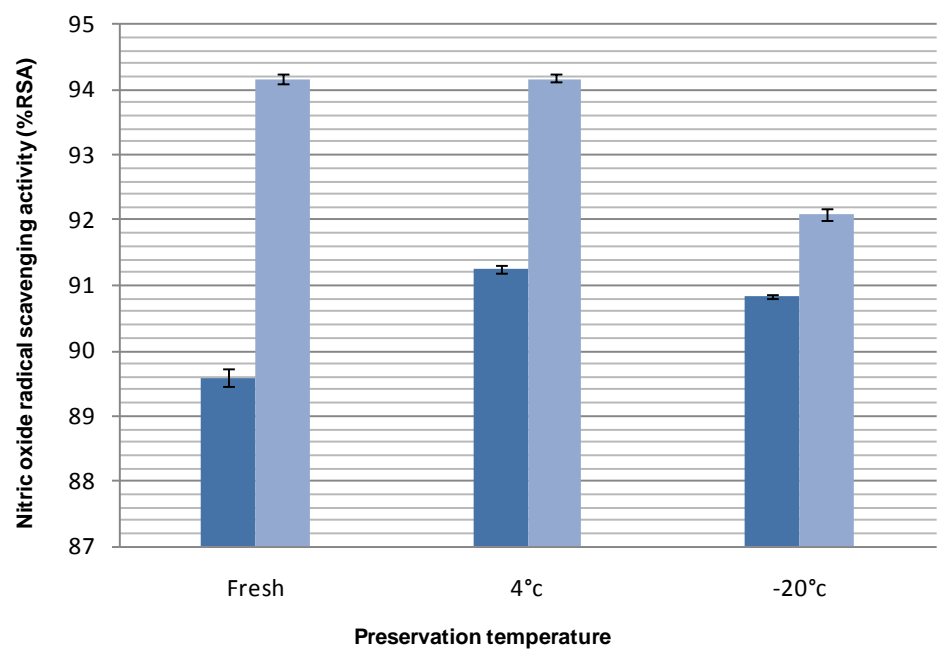

- V. amygdalina broad (\%RSA)

V. amygdalina small (\%RSA)

Figure 8. Effect of preservation on nitric oxide radical scavenging activity (\%RSA) of leaves. $4^{\circ} \mathrm{C}$, leaves preserved by refrigeration $\left(4^{\circ} \mathrm{C}\right)$ for two weeks; and $-20^{\circ} \mathrm{C}$, leaves preserved by freezing $\left(-20^{\circ} \mathrm{C}\right)$ for two weeks. 
was significantly decreased at $\mathrm{p}<0.05$ for both bitter leaf varieties. Chlorophyll content is used to assess both the visual quality of the samples (green index) and its nutritional quality. Since chlorophyll is considered crucial to the final product acceptance; the decrease in chlorophyll as observed in the current study could affect the final product acceptance of the vegetable. Phenol and flavonoid contents are antioxidants that can be more easily preserved at $4^{\circ} \mathrm{C}$ compared with $-20^{\circ} \mathrm{C}$. However, irrespective of temperature, there was a significant reduction in total soluble protein and reducing sugars. Antioxidants studied also showed a significant increase at a storage temperature of $4^{\circ} \mathrm{C}$. Thus, it could be concluded from the current study that $V$. amygdalina stored at $4^{\circ} \mathrm{C}$ retains more of its nutritional and medicinal properties compared with when stored at $-20^{\circ} \mathrm{C}$. This finding would be useful during short-term preservation of bitter leaves for soup preparation and/or its aqueous extract for ethnomedicinal purposes, especially the small leaf variety.

\section{References}

[1] Egedigwe, C.A. (2010) Effect of Dietary Incorporation of Vernonia amygdalina and Vernonia colorata on Blood Lipid Profile and Relative Organ Weights in Albino Rats. M.Sc. Dissertation, Michael Okpara University of Agriculture, Umudike.

[2] Igile, G.O., Oleszk, W., Burda, S. and Juryzsta, M. (1995) Nutritional Assessment of V. amygdalina Leaves in Growing Mice. Journal of Agricultural and Food Chemistry, 93, 2162-2166. http://dx.doi.org/10.1021/jf00056a038

[3] Owen, O.J., Amakiri, A.O., David, E.U., Nyeche, V.N. and Ndor, L. (2009) Proximate Composition, Energy Content and Mineral Profile of Vernonia amygdalina (Bitter Leaf) Meal. Proceedings of 14th Annual Conference Animal Science Association of Nigeria, Ogbomoso, 14-17 September 2009, 173-176.

[4] Sobukola, O.P. and Dairo, O.U. (2007) Modeling Drying Kinetics of Fever Leaves (Ocimum viride) in a Convective Hot Air Dryer. Nigerian Food Journal, 25, 145-153. http://dx.doi.org/10.4314/nifoj.v25i1.33663

[5] Akah, P.A. and Okafor, C.I. (1992) Blood Sugar Lowering Effect of V. amaygdalina Del. in Experimental Rabbit Model. Phytotherapy Research, 6, 171-173. http://dx.doi.org/10.1002/ptr.2650060318

[6] Uhegbu, F.O. and Ogbuehi, K.J. (2004) Effect of the Aqueous Extract (Crude) of Leaves of Vernonia amygdalina on Blood Glucose, Serum Cholesterol and Serum Albumin Levels in Alloxan Induced Diabetic Albino Rats. Global Journal of Pure and Applied Sciences, 10, 189-194. http://dx.doi.org/10.4314/gjpas.v10i1.16380

[7] Nwajo, H.U. (2005) Efficacy of Aqueous Leaf Extract of Vernonia amygdalina on Plasma Lipoproteins and Oxidative Status in Diabetic Rat Model. Nigerian Journal of Physiological Sciences, 20, 39-42.

[8] Akah, P.A., Okoli, C.O. and Nwafor, S.V. (2002) Phytotherapy in the Management of Diabetes Mellitus. Journal of Natural Remedies, 2, 59-65.

[9] Oboh, G. (2003) Hemolytic Effect of Saponin Extract from Vernonia amygdalina (Bitter Leaf) on Human Erythrocyte. Applied Natural Science Research, 1, 25-29.

[10] Masaba, S.C. (2000) The Antimalarial Activity of Some Traditional Medicinal Plants. Ethiopian Journal of Health Development, 13, 211-216.

[11] Akinpelu, D.A. (1999) Antimicrobial Activity of Vernonia amygdalina Leaves. Fitoterapia, 70, 432-434. http://dx.doi.org/10.1016/S0367-326X(99)00061-1

[12] Kafaru, E. (1994) Immense Help for Natures Workshop Public. Elkaf Health Services Ltd, Benin-City, 54-58.

[13] Erasto, P., Grierson, D.S. and Afolayan, A.J. (2007) Evaluation of Antioxidant Activity and the Fatty Acid Profile of the Leaves of Vernonia amygdalina Growing in South Africa. Food Chemistry, 104, 636-642. http://dx.doi.org/10.1016/j.foodchem.2006.12.013

[14] Nwanjo, H.U. (2005) Efficacy of Aqueous Leaf Extract of Vernonia amygdalina on Plasma Lipoprotein and Oxidative Status in Diabetic Rat Models. Nigerian Journal of Physiological Sciences, 20, 39-42.

[15] Adaramoye, O.A., Akintayo, O., Achem, J. and Fatunso, M.A. (2008) Lipid Lowering Effects of Methanolic Extracts of Vernonia amygdalina Leaves in Rats Fed on High Cholesterol Diet. Vascular Health and Risk Management, 4, 235241. http://dx.doi.org/10.2147/vhrm.2008.04.01.235

[16] Fafunso, A. and Bassir, O.O. (1977) Nigerian Medicinal Plants. University of Ibadan Press, Ibadan, 121.

[17] Delcour, J.A. and Piet, V.L. (1988) Hydrolysable Tannins for Chillproofing Beers. The New Brewer, 5.

[18] Arnon, D. (1949) Copper Enzymes in Isolated Chloroplasts. Phenoloxidase in Beta vulgaris. Plant Physiology, 24, 115. http://dx.doi.org/10.1104/pp.24.1.1

[19] Reezi, S., Babalar, M. and Kalantari, S. (2009) Silicon Alleviates Salt Stress, Decreases Malondialdehyde Content and Affects Petal Color of Salt-Stressed Cut Rose (Rosa xhybrida L.) "Hot Lady". African Journal of Biotechnology, 8, 1502-1508. 
[20] Jia, Z., Tang, M. and Wu, J. (1999) The Determination of Flavonoid Contents of Murlberry and Their Scavenging Effects on Superoxide Radicals. Food Chemistry, 64, 555-559. http://dx.doi.org/10.1016/S0308-8146(98)00102-2

[21] Singleton, V.L. and Rossi, J.A. (1965) Colorimetry of Total Phenolics with Phosphomolybdic-Phosphotungstic Acid Reagents. American Journal of Enology and Viticulture, 16, 144-158.

[22] Oyaizu, M. (1986) Studies on Products of Browning Reactions: Antioxidative Activities of Products of Browning Reaction Prepared from Glucosamine. The Japanese Journal of Nutrition and Dietetics, 44, 307-315. http://dx.doi.org/10.5264/eiyogakuzashi.44.307

[23] Hatano, T., Kagawa, H., Yasuhara, T. and Okuda, T. (1988) Two New Flavonoids and Other Constituents in Licore Root: Their Relative Astringency and Radical Scavenging Affects. Chemical \& Pharmaceutical Bulletin, 36, 20902097. http://dx.doi.org/10.1248/cpb.36.2090

[24] Marcocci, L., Packer, L., Droy-Lefai, M.T., Sekaki, A. and Gardes-Albert, M. (1994) Antioxidant Action of Ginkgo biloba Extracts EGb 761. Methods in Enzymology, 234, 462-475. http://dx.doi.org/10.1016/0076-6879(94)34117-6

[25] Miller, G.L. (1959) Use of the Dinitrosalicylic Acid Reagent for the Determination of Reducing Sugar. Analytical Chemistry, 31, 426-428. http://dx.doi.org/10.1021/ac60147a030

[26] Gornall, A., Bardsmill, C.T. and David, M.M. (1949) Determination of Serum Proteins by Means of the Biuret Reaction. The Journal of Biological Chemistry, 177, 751-766.

[27] Cătunescu, G.M., Tofană, M., Mureşan, C., Ranga, F., David, A. and Muntean, M. (2012) The Effect of Cold Storage on Some Quality Characteristics of Minimally Processed Parsley (Petroselinum crispum), Dill (Anethum graveolens) and Lovage (Levisticum officinale). Bulletin of the University of Agricultural Sciences and Veterinary Medicine ClujNapoca Agriculture, 69.

[28] Agüero, M.V., Barg, M.V., Yommi, A., Camelo, A. and Roura, S.I. (2008) Postharvest Changes in Water Status and Chlorophyll Content of Lettuce (Lactuca sativa L.) and Their Relationship with Overall Visual Quality. Journal of Food Science, 73, S47-S55.

[29] Kidmose, U., Edelenbos, M., Nørbæk, R. and Christensen, L.P. (2002) Color Stability in Vegetables. In: MacDougall, D.B., Ed., Color in Food: Improving Quality, CRC Press/Woodhead Publishing Limited, Cambridge, 179-232. http://dx.doi.org/10.1533/9781855736672.2.179

[30] Abe, K. and Watada, A.E. (1991) Ethylene Absorbent to Maintain Quality of Lightly Processed Fruits and Vegetables. Journal of Food Science, 56, 1589-1592. http://dx.doi.org/10.1111/j.1365-2621.1991.tb08647.x

[31] Bolin, H.R. and Huxsoll, C.C. (1991) Effect of Preparation Procedures and Storage Parameters on Quality Retention of Salad-Cut Lettuce. Journal of Food Science, 56, 60-62. http://dx.doi.org/10.1111/j.1365-2621.1991.tb07975.x

[32] Haard, F.N. (1993) Características de los tejidos vegetales comestibles. In: Fennema, O.R., Ed., Química de los Alimentos, 2nd Edition, Acribia, Zaragoza, 961-1024.

[33] Watada, A.E., Abe, K. and Yamuchi, N. (1990) Physiological Activities of Partially Processed Fruits and Vegetables. Food Technology, 44, 116-122.

[34] Yamuchi, N. and Watada, A.E. (1991) Regulated Chlorophyll Degradation in Spinach Leaves during Storage. Journal of the American Society for Horticultural Science, 116, 58-62.

[35] Shioi, Y., Tomita, N., Tsuchiya, T. and Takamiya, K. (1996) Conversion of Chlorophyllide to Pheophorbide by MgDechelating Substance in Extracts of Chenopodium album. Plant Physiology and Biochemistry, 34, 41-47.

[36] Jacob-Wilk, D., Holland, D., Goldschmidt, E.E., Riov, J. and Eyal, Y. (1999) Chlorophyll Breakdown by Chlorophyllase: Isolation and Functional Expression of the Chlase 1 Gene from Ethylene-Treated Citrus Fruit and Its Regulation during Development. The Plant Journal, 20, 653-661. http://dx.doi.org/10.1046/j.1365-313X.1999.00637.x

[37] Ferruzzi, M.G. and Schwartz, S. (2001) UNIT F4.1. Overview of Chlorophylls in Foods. Current Protocols in Food Analytical Chemistry, Published Online.

[38] Fahey, J.W., Stephenson, K.K., Dinkova-Kostova, A.T., Egner, P.A., Kensler, T.W. and Talalay, P. (2005) Chlorophyll, Chlorophyllin and Related Tetrapyrroles Are Significant Inducers of Mammalian Phase 2 Cytoprotective Genes. Carcinogenesis, 26, 1247-1255. http://dx.doi.org/10.1093/carcin/bgi068

[39] Chaovanalikit, A. and Wrolstad, R.E. (2004) Total Anthocyanins and Total Phenolics of Fresh and Processed Cherries and Their Antioxidant Properties. Journal of Food Science, 69, FCT67-FCT72. http://dx.doi.org/10.1111/j.1365-2621.2004.tb17858.x

[40] Turkmen, N., Sari, F. and Velioglu, Y.S. (2005) The Effect of Cooking Methods on Total Phenolics and Antioxidant Activity of Selected Green Vegetables. Food Chemistry, 93, 713-718. http://dx.doi.org/10.1016/j.foodchem.2004.12.038

[41] Majewska, M., Skrzycki, M., Podsiad, M. and Czeczot, H. (2011) Evaluation of Antioxidant Potential of Flavonoids: An in Vitro Study. Acta Poloniae Pharmaceutica, 68, 611-615. 
[42] Murugan, S.B., Reshma, A., Deepika, R., Balamurugan, S. and Sathishkumar, R. (2013) Antioxidant Capacities of Amaranthus tristis and Alternanthera sessilis: A Comparative Study. Journal of Medicinal Plants Research, 7, 22302235.

[43] Stangeland, T., Remberg, S.F. and Lye, K.A. (2009) Total Antioxidant Activity in 35 Ugandan Fruits and Vegetables. Food Chemistry, 113, 85-91. http://dx.doi.org/10.1016/j.foodchem.2008.07.026

[44] Wills, R., McGlasson, B., Graham, D. and Joyce, D. (1998) Post Harvest: An Introduction to the Physiology and Handling of Fruits, Vegetables and Ornamentals. 4th Edition, University of New South Wales Press Ltd., Sydney.

[45] Singh, G.D., Siingh, S., Jindal, N., Bawa, A.S. and Saxena, D.C. (2010) Physico-Chemical Characteristics and Sensory Quality of Singhara (Trapa natans L.): An Indian Water Chestnut under Commercial and Industrial Storage Conditions. African Journal of Food Science, 4, 693-702. 